\title{
EFFECT OF RE-MATING INTERVAL AFTER THE FIRST PARTURITION ON THE LITTER PARAMETERS, MILK YIELD AND REPRODUCTION TRAITS OF RABBIT DOES
}

\author{
Shereen. S. Ghoneim ${ }^{1}$; I. El-Wardany²; A. Farid; A.H. Ahmed ${ }^{2}$ \\ and E.M. Abd El-Kaffy \\ 1- Rabbit Breeding Research Dept., Animal Prod. Res. Inst., Agric. Res. Center, Ministry of \\ Agric., Dokki, Giza, Egypt \\ 2- Poultry Production Dept., Fac. of Agric., Ain Shams Univ., Cairo, Egypt
}

Keywords: Rabbit does, Rabbits breed, Re-mating interval, Productive and Reproductive Performance, Milk yield

\section{ABSTRACT}

A total number of 120 nulliparous APRI and Baladi Black does (60 does for each breed) were mated at 5 months of age at the beginning of the breeding season (during September) to study the effect of re-mating interval after the first parturition on the litter parameters, milk yield per day and reproduction traits. All does were randomly divided into three equal groups according to reproductive rhythm: The $1^{\text {st }}$ group: post partum (PP), the $2^{\text {nd }}$ group: 11 days after parturition (P11), and the $3^{\text {rd }}$ group: Post weaning (PW) .The body weight of P11 does were slightly higher than that of PP or PW groups. The re- mating interval groups during second parity had significant $(P<0.05)$ effects on litter traits at weaning. Litter size and Litter weight at weaning age in PW group were higher significantly $(P<0.05)$ than those in $P P$ and $P 11$ groups. Litter weight at 21 days of age in $\mathrm{PW}$ and $\mathrm{P} 11$ groups were higher significantly $(P<0.05)$ than those in PP group. The PW group had significant higher litter size at weaning than those in PP group. Daily milk yield (DMY) after second parity was affected significantly by re-mating interval groups in the third and fourth week of suckling period. GL in PP group was higher significantly $(\mathrm{P}<0.05)$ comparing with $\mathrm{P} 11$ or $\mathrm{PW}$ groups. The values of litter size and weight traits were better for APRI does comparing with BB except litter weight at 21 days. The difference in results between the two breeds in daily milk yield showed generally higher trend of daily milk yield for APRI over BB. The Kindling interval and the gestation period were significantly $(P<0.05)$ affected by interaction of remating interval group and breed. In conclusion, applying a lengthened period after the first kindling (by more than 10 days or after weaning) had a favorable effect on the does' production.

\section{INTRODUCTION}

The most important factors that determines the rabbit does' production is their body condition (Pascual, 2010), and the age at first insemination (Rommers et al 2002 and Bonanno et al 2004). High longevity and high level production can only be expected if the energy depots of rabbit does is sufficient. During the final phase of gestation that coincides with the lactation peak the does show energy deficit (Xiccato, 1996), thus feed intake cannot provide them with their energy demand. The primiparous lactating does loose an exceptionally large part of their fat depots that can be explained with the growth of their own body as they inseminated after reaching $75-80 \%$ of their adult weight. The does' condition is the most critical after the first kindling. Matics et al (2011) examined the effect of the length of the period between the first kindling and the next inseminations on the does' production .Does were sorted to three groups and inseminated 11, 18, or 25 days after the first kindling. They observed that no significant differences were found for the does' body weight, litter size, suckling mortality, litter and individual weight at day 21. Despite of the small differences 
that were recorded for these traits, the productivity per 100 inseminations substantial alterations were observed for the total number of kits born, total number of kits born alive, total number of kits at day 21 and total kit's weight at day 21 were higher in 25 days after the first kindling than those in other groups (11 and 18 day). They concluded that it is worth to re-inseminate the does 1-2 weeks later for improving their condition and production level. So, the aim of the present study is to examine the influence of re-mating intervals after the first parturition on productive parameters and lactation performance of rabbit does. The interaction effect of different re-mating intervals and genotypes of rabbit and their influence on the performance of rabbit does is also studied.

\section{MATERIALS AND METHODS}

The experiment was conducted at the Rabbits Farm of Sakha Station, Animal Production Research Institute, Agriculture Research Center, Egypt. A total number of 120 nulliparous APRI and Baladi Black does (60 does for each breed) were mated at 5 months of age at the beginning of the breeding season (during September). All does were housed in individually wire cage $(60 \times 50 \times 35$ $\mathrm{cm})$ provided with feeders, automatic watering nipple drinkers for all times and all rabbits fed adlibitum with commercial pellet containing $16 \%$ crude protein, $13 \%$ crude fiber and $2.4 \%$ fat . Diet was formulated according to NRC, (1977) for rabbits. Nest boxes measures were $30 \times 30 \times 25 \mathrm{~cm}$. Animals were kept under natural day light. All the experimental animals were reared under the same environmental and managemental conditions while the ventilation and temperature were natural.

Sex ratio was ranged from 3-5 female to 1 male depending upon the available numbers throughout the experiment. Natural mating was used at all the times of experimental period. The rabbit does after first parturition were randomly sorted into three groups according to different their re-mating interval as follow ; group 1 was re-mated 2 days (PP), group 2 was re-mated at the $11^{\text {th }}$ day post-partum (P11) and group3, was re-mated after weaning at 35 days of age (PW). All does were re-mated at day 11 after kindling in the next parities. The weights of does stock are recorded after each kindling and mating. The litter size and weight traits were recorded and included: the litter size at birth (total number of young born and born alive), at 21 days and at weaning age, the mean live weight of the young at birth, 21 days and at weaning. The daily milk yield by grams (DMY) measured by differences in litter body weight before and after suckling and recorded weekly up to weaning during all parities. While, reproductive traits measured by days (gestation length (GL); kindling interval (KI); number of service per conception (NSC) and days open (DO) were measured only after second parity (from 3 to 6 parities) in rabbit does as affected by different re-mating interval during second parity. All possible interactions were done for parities after $2^{\text {nd }}$ parity. In the evaluation the first kindling was not considered because they were independent of the time of re-mating.

Statistical analyses of rabbit performance were conducted using SAS (2001). Data are presented to equation for the analysis of the $2^{\text {nd }}$ parity:

$$
Y_{i j k}=\mu+B_{i}+R_{j}+(B R)_{i j}+e_{i j k}
$$

Where:

$Y_{i j k}=$ observation, $\mu=$ overall mean, $B_{i}=$ Fixed effect of breed, $R_{j}=$ Fixed effect of re-mating interval after first parturition, $(R B)_{i j k}=$ Effect of interaction between breed and re-mating interval, $e_{i j k}=$ Random error. Differences among means were detected by using Duncan's multiple range test (Duncan, 1955).

While data of the next parities (from 3 to 6 parities) are analysed according to the following model:

$$
Y_{i j l k}=\mu+B_{i}+R_{j}+P_{l}+(B R)_{i j}+e_{i j l k}
$$

All symbols as in the $1^{\text {st }}$ model except $\mathrm{PI}=$ Fixed effect of $I^{\text {th }}$ parity, $\mathrm{e}_{\mathrm{ijlk}}=$ Random error.

\section{RESULTS AND DISCUSSION}

\subsection{Productive performance during the second parity}

Results in Tables 1, 2 and 3 for body weight, litter and milk traits during second parity were affected by the three re-mating interval groups of PP, $\mathrm{P} 11$ and PW.

\section{Body weight of the does}

Results in Table1 showed unsignificant differences among the three groups (PP, P11 and PW) for body weight of does with slightly higher in $\mathrm{P} 11$ than that of the PP or PW does. 
Table 1. Body weights of the rabbit does at kindling and at mating during second parity as affected by re-mating intervals after first kindling (Means $\pm \mathrm{SE})$.

\begin{tabular}{|c|c|c|}
\hline $7^{\text {Traits }}$ & \multicolumn{2}{|c|}{ Doe Weight (g) } \\
\hline During $2^{\text {nd }}$ Parity & At kindling & At mating \\
\hline PP & $3118.4 \pm 82.3$ & $3126.3 \pm 53.6$ \\
\hline P11 & $3184.6 \pm 94.9$ & $3196.1 \pm 57.7$ \\
\hline PW & $3136.7 \pm 71.0$ & $3144.8 \pm 44.9$ \\
\hline
\end{tabular}

Reproductive rhythm: PP, post partum; P11, 11 days after parturition; PW, post weaning.
Effect of re-mating interval (groups) on production performances

The results of the re-mating interval (groups) effects on litter size and litter weight traits are presented in Table (2).

It could be noticed that the re- mating interval had significant $(P<0.05)$ effects on litter size at weaning and in all litter weight except litter weight at birth. Litter size and weight at weaning age in PW group were significantly $(P<0.05)$ higher (in general) followed by $\mathrm{P} 11$ group than PP group, the same trend was noticed for litter size at 21 days.

Table 2. Litter parameter of the rabbit does during second parity as affected by re-mating intervals after first kindling (Means $\pm \mathrm{SE}$ ).

\begin{tabular}{|c|c|c|c|c|c|c|c|}
\hline Parity time & \multicolumn{4}{|c|}{ Litter size } & \multicolumn{3}{|c|}{ Litter weight } \\
\hline During $2^{\text {nd }}$ Parity & Birth & Alive & 21 days & Weaning & Birth & 21 days & Weaning \\
\hline PP & $\begin{array}{c}8.6 \\
\pm 0.45\end{array}$ & $\begin{array}{c}8.6 \\
\pm 0.45\end{array}$ & $\begin{array}{c}6.2 \\
\pm 0.45\end{array}$ & $\begin{array}{l}5.2^{\mathrm{b}} \\
\pm 0.46\end{array}$ & $\begin{array}{l}427.5 \\
\pm 28.5\end{array}$ & $\begin{array}{l}1479.5^{b} \\
\pm 111.5\end{array}$ & $\begin{array}{l}2125.2^{c} \\
\pm 210.6\end{array}$ \\
\hline P11 & $\begin{array}{c}8.6 \\
\pm 0.45\end{array}$ & $\begin{array}{c}8.5 \\
\pm 0.44\end{array}$ & $\begin{array}{c}6.5 \\
\pm 0.44\end{array}$ & $\begin{array}{l}5.7^{\mathrm{ab}} \\
\pm 0.44\end{array}$ & $\begin{array}{l}413.4 \\
\pm 27.9\end{array}$ & $\begin{array}{l}1688.9^{a} \\
\pm 107.7\end{array}$ & $\begin{array}{l}2526.4^{\mathrm{b}} \\
\pm 202.6\end{array}$ \\
\hline PW & $\begin{array}{c}8.4 \\
\pm 0.39\end{array}$ & $\begin{array}{c}8.4 \\
\pm 0.38\end{array}$ & $\begin{array}{c}7.0 \\
\pm 0.37\end{array}$ & $\begin{array}{r}6.3^{\mathrm{a}} \\
\pm 0.38\end{array}$ & $\begin{array}{r}449.3 \\
\pm 24.4\end{array}$ & $\begin{array}{c}1751.5^{\mathrm{a}} \\
\pm 92.3\end{array}$ & $\begin{array}{l}2963.6^{\mathrm{a}} \\
\pm 173.7\end{array}$ \\
\hline
\end{tabular}

$a, b$ Means in the same column with different superscripts are significantly different $(P \leq 0.05)$

${ }^{1}$ Reproductive rhythm: PP, post-partum; P11, 11 days after parturition; PW, post weaning.

Table3. Effect of re-mating intervals (groups) on daily milk yield during second parity in rabbit does (Means $\pm \mathrm{SE}$ ).

\begin{tabular}{|l|l|l|l|l|}
\hline \multicolumn{1}{|c|}{ Traits } & \multicolumn{4}{|c|}{ daily milk yield (DMY) } \\
Parity time & $\mathbf{M}_{\mathbf{1}}$ & $\mathbf{M}_{\mathbf{2}}$ & $\mathbf{M}_{\mathbf{3}}$ & $\mathbf{M}_{\mathbf{4}}$ \\
\hline During 2 ${ }^{\text {nd }}$ Parity & $68.7 \pm 10.2$ & $96.1 \pm 8.0$ & $90.8 \pm 8.1$ & $75.6 \pm 7.7$ \\
\hline PP & $73.9 \pm 10.6$ & $86.9 \pm 7.6$ & $85.7 \pm 7.9$ & $69.8 \pm 7.4$ \\
P11 & $74.5 \pm 8.9$ & $88.9 \pm 6.4$ & $93.9 \pm 7.1$ & $82.6 \pm 6.6$ \\
PW &
\end{tabular}

${ }^{1}$ Reproductive rhythm: PP, post-partum; P11, 11 days after parturition; PW, post weaning. $\mathbf{M}_{1-4}$ : Milk yield from $1^{\text {st }}$ to $4^{\text {th }}$ week. 
Results of Table (3) showed that DMY was not significantly affected by re-mating interval groups during second parity. These results revealed that DMY in the PW group were higher in all weeks except in the second week than the other two groups.

It appears from the results that no significant differences were found for the does' body weight (Tables 1, 2, 3). However, significant differences among the groups were found for litter size and litter weight at weaning. This may be attributed to suckling mortality. Other authors (Xiccato et al 2005; Castellini et al 2006; Feugier and FortunLamothe, 2006 and Szendrő et al 2008) conducted several experiments where the insemination at day 11 was compared to a more extensive reproduction rhythm. In these experiments the period between kindling and re-insemination was different throughout the whole productive period. This is in agreement with the present study where the difference was confined to the first kindling.

\subsection{Productive performance after second parity}

\section{Body weight of the does}

Table 4. Body weights of the rabbit does at kindling and mating at next parities as affected by remating intervals (Means $\pm \mathrm{SE}$ ).

\begin{tabular}{|c|c|c|}
\hline Parity time & \multicolumn{2}{|c|}{ Doe Weight $(\mathbf{g})$} \\
\hline Next parities & At kindling & At mating \\
\hline PP & $3007.6 \pm 46.9$ & $3150.7 \pm 38.9$ \\
P11 & $3050.7 \pm 43.9$ & $3077.9 \pm 42.8$ \\
PW & $3183.4 \pm 34.8$ & $3180.6 \pm 30.6$ \\
\hline
\end{tabular}

Reproductive rhythm: PP, post-partum; P11, 11 days after parturition; PW, post weaning.

In next or later parities (after the second parity), showed no differences among groups on doe's body weight. However, slightly increases were noticed for does which mated after weaning (PW) than the other two groups.

Table 5. Litter parameters for the next parities as affected by re- mating interval of the doe rabbits (Means $\pm \mathrm{SE})$.

\begin{tabular}{|c|c|c|c|c|c|c|c|}
\hline Traits & \multicolumn{4}{|c|}{ Litter size } & \multicolumn{3}{|c|}{ Litter weight } \\
\hline Next parities & Birth & Alive & $\begin{array}{c}21 \\
\text { days }\end{array}$ & Weaning & Birth & 21 days & Weaning \\
\hline PP & $\begin{array}{c}8.5 \\
\pm 0.35\end{array}$ & $\begin{array}{c}8.4 \\
\pm 0.35\end{array}$ & $\begin{array}{c}7.0 \\
\pm 0.39\end{array}$ & $\begin{array}{c}5.8^{\mathrm{b}} \\
\pm 0.41\end{array}$ & $\begin{array}{l}412.1 \\
\pm 20.6\end{array}$ & $\begin{array}{r}1846.0 \\
\pm 109.9\end{array}$ & $\begin{array}{l}2786.4 \\
\pm 203.1\end{array}$ \\
\hline P11 & $\begin{array}{c}8.5 \\
\pm 0.38\end{array}$ & $\begin{array}{c}8.4 \\
\pm 0.37\end{array}$ & $\begin{array}{c}7.0 \\
\pm 0.43\end{array}$ & $\begin{array}{l}6.2^{\mathrm{ab}} \\
\pm 0.45\end{array}$ & $\begin{array}{l}403.9 \\
\pm 22.1\end{array}$ & $\begin{array}{l}1756.0 \\
\pm 118.8\end{array}$ & $\begin{array}{l}2983.9 \\
\pm 223.6\end{array}$ \\
\hline PW & $\begin{array}{c}8.9 \\
\pm 0.36\end{array}$ & $\begin{array}{r}8.5 \\
+0.35\end{array}$ & $\begin{array}{c}7.3 \\
\pm 0.41\end{array}$ & $\begin{array}{c}6.6^{\mathrm{a}} \\
\pm 0.42\end{array}$ & $\begin{array}{l}420.7 \\
\pm 21.0\end{array}$ & $\begin{array}{r}1804.9 \\
\pm 113.1\end{array}$ & $\begin{array}{r}3139.8 \\
\pm 209.7\end{array}$ \\
\hline
\end{tabular}

\footnotetext{
${ }^{a, b}$ Means in the same column with different superscripts are significantly different.

${ }^{1}$ Reproductive rhythm: PP, post-partum; P11, 11 days after parturition; PW, post weaning.
}

\section{Effect of re-mating interval (groups) on produc- tion performances}

Re-mating interval groups during parities after second parity had no significant effects on litter traits except for litter size at weaning (Table 5) which were significantly and higher in the post weaning (PW) group than the other two groups. As in show in table $5, \mathrm{PW}$ group had a higher litter size and weight than the other two groups except for litter weight at 21 days.

Daily milk yield after second parity was affected significantly by re-mating interval groups in third and fourth week of suckling period (Table 6). The highest values in daily milk yield were shown in first and second weeks for PP group and in the third and fourth week of suckling period for P11 group. 
Effect of re-mating interval after the first parturition on the litter parameters, milk yield and reproduction traits of rabbit does

Table 6. Effect of re- mating interval on daily milk yield at next parities for doe rabbits (Means $\pm \mathrm{SE}$ ).

\begin{tabular}{|c|c|c|c|c|}
\hline Parity time & \multicolumn{4}{|c|}{ daily milk yield } \\
\cline { 1 - 4 } Next parities & $\mathbf{M}_{\mathbf{1}}$ & $\mathbf{M}_{\mathbf{2}}$ & $\mathbf{M}_{\mathbf{3}}$ & $\mathbf{M}_{\mathbf{4}}$ \\
\hline PP & $84.5 \pm 6.8$ & $95.8 \pm 7.4$ & $79.6^{\mathrm{b}} \pm 6.6$ & $69.4^{\mathrm{b}} \pm 5.9$ \\
P11 & $78.9 \pm 7.2$ & $91.5 \pm 7.9$ & $91.3^{\mathrm{a}} \pm 7.1$ & $80.3^{\mathrm{a}} \pm 6.5$ \\
PW & $82.2 \pm 6.9$ & $95.2 \pm 7.6$ & $85.4^{\mathrm{ab}} \pm 6.7$ & $78.9^{\mathrm{a}} \pm 6.0$ \\
\hline
\end{tabular}

\footnotetext{
${ }^{a, b}$ Means in the same column with different superscripts are significantly different.

${ }^{1}$ Reproductive rhythm: PP, post partum; P11, 11 days after parturition; PW, post weaning

$\mathbf{M}_{1-4}$ : Milk yield from $1^{\text {st }}$ to $4^{\text {th }}$ week.
}

\section{Effect of re-mating interval (groups) on repro- ductive performances}

All reproductive traits, did not affected with remating intervals during second parity except gestation length $(G L)$ which was significantly $(P<0.05)$ influenced (Table 7). The gestation length (GL) in PP group was higher significantly comparing with other groups (Table 7). In this respect, results in Table (2) showed higher litter size and weight at weaning in $\mathrm{PW}$ group followed by $\mathrm{P} 11$ group, while results in table 7 reveled short GL in P11 and PW groups. This was in agreement with Hilmy (1991) who observed a linear decrease in $G L$ with the increase of litter size and weight.

Table 7. Body weight and reproductive traits for doe rabbits in next parities ( 3 up to 6 ) as affected by re-mating interval groups during second parity

\begin{tabular}{|c|c|c|c|c|c|}
\hline Traits & Doe weight (g) & \multicolumn{4}{|c|}{ Reproductive traits } \\
\hline Next parities & At mating & NSC & DO(d) & KI(d) & GL(d) \\
\hline PP & $3150.7 \pm 38.9$ & $1.57 \pm 0.12$ & $12.6 \pm 2.9$ & $52.6 \pm 3.0$ & $32.0 \pm 0.20^{\mathrm{a}}$ \\
P11 & $3077.9 \pm 42.8$ & $1.50 \pm 0.13$ & $14.1 \pm 3.3$ & $52.7 \pm 3.2$ & $31.6 \pm 0.21^{\mathrm{b}}$ \\
PW & $3180.6 \pm 30.6$ & $1.37 \pm 0.12$ & $13.2 \pm 3.0$ & $50.9 \pm 3.1$ & $31.6 \pm 0.20^{\mathrm{b}}$ \\
\hline
\end{tabular}

a,b Means in the same column with different superscripts are significantly different.

${ }^{1}$ Reproductive rhythm: PP, post partum; P11, 11 days after parturition; PW, post weaning.

\subsection{Interactions between breed and re-mating interval (groups)on rabbit doe performance}

Results of some productive and reproductive traits of the two breeds of rabbits does as affected by breed $\times$ re-mating interval in parities after second one (from $3^{\text {rd }}$ to $6^{\text {th }}$ parity) are presented in Tables $(8,9$ and 10$)$.

The effects of re-mating interval of the second parturition $\times$ breed on the litter characteristics were significant affected on litter size and weight except for alive litter size and litter weight at 21 days as shown in (Table 8).
The results showed that values of litter traits performance were however better for APRI does than $\mathrm{BB}$ in all re-mating system groups. Litter size and weight (in most cases) were higher for PW group than the other two groups.

Effect of interaction of re-mating interval group during second parturition and breed on daily milk yield is shown in Table (9).It is clear that the remating interval was strong influenced in the most of weeks in milk yield. The difference in result between the two breed APRI and Baladi black (BB) in daily milk yield showed generally higher trend of daily milk yield for APRI over BB in all weeks of suckling period (Table 9). 
Table 8. Interaction effects of postpartum re-mating interval (groups) $x$ breed on litter parameters for rabbit does after second parity (Means \pm SE)

\begin{tabular}{|c|c|c|c|c|c|c|c|c|}
\hline \multirow[t]{3}{*}{ Traits } & \multirow{3}{*}{ Breed $^{1}$} & \multicolumn{7}{|c|}{ Next Parities } \\
\hline & & \multicolumn{4}{|c|}{ Litter size } & \multicolumn{3}{|c|}{ Litter weight } \\
\hline & & Birth & Alive & 21 days & Weaning & Birth & 21 days & Weaning \\
\hline \multirow{4}{*}{ PP } & \multirow{2}{*}{ APRI } & $9.4^{\mathrm{a}}$ & 9.2 & $7.3^{\mathrm{ab}}$ & $6.3^{\mathrm{ab}}$ & $455.0^{\mathrm{a}}$ & 1808.9 & 2877.8 \\
\hline & & \pm 0.38 & \pm 0.37 & \pm 0.39 & \pm 0.40 & \pm 21.8 & \pm 110.3 & \pm 202.2 \\
\hline & \multirow{2}{*}{ BB } & $7.5^{\mathrm{b}}$ & 7.4 & $6.5^{\mathrm{b}}$ & $5.4^{b}$ & $361.1^{\mathrm{b}}$ & 1917.3 & 2764.6 \\
\hline & & \pm 0.51 & \pm 0.52 & \pm 0.61 & \pm 0.65 & \pm 30.9 & \pm 169.5 & \pm 323.5 \\
\hline \multirow{4}{*}{ P11 } & \multirow{2}{*}{ APRI } & $9.2^{\mathrm{a}}$ & 9.1 & $7.5^{\mathrm{a}}$ & $6.8^{\mathrm{a}}$ & $447.5^{a}$ & 1743.6 & 3181.5 \\
\hline & & \pm 0.40 & \pm 0.39 & \pm 0.44 & \pm 0.46 & \pm 23.0 & \pm 123.0 & \pm 228.6 \\
\hline & \multirow{2}{*}{ BB } & $7.8^{b}$ & 7.5 & $6.4^{\mathrm{b}}$ & $5.2^{b}$ & $349.5^{\mathrm{b}}$ & 1753.7 & 2610.7 \\
\hline & & \pm 0.59 & \pm 0.56 & \pm 0.55 & \pm 0.62 & \pm 33.4 & \pm 154.5 & \pm 308.1 \\
\hline \multirow{4}{*}{ PW } & \multirow{2}{*}{ APRI } & $9.4^{\mathrm{a}}$ & 9.0 & $7.5^{\mathrm{a}}$ & $6.9^{\mathrm{a}}$ & $452.4^{\mathrm{a}}$ & 1777.7 & 3204.5 \\
\hline & & \pm 0.39 & \pm 0.38 & \pm 0.42 & \pm 0.44 & \pm 22.5 & \pm 118.3 & \pm 219.6 \\
\hline & \multirow{2}{*}{ BB } & $8.4^{\mathrm{ab}}$ & 8.1 & $7.1^{\mathrm{ab}}$ & $6.5^{\mathrm{a}}$ & $393.1^{\mathrm{ab}}$ & 1841.9 & 3130.6 \\
\hline & & \pm 0.45 & \pm 0.44 & \pm 0.48 & \pm 0.49 & \pm 26.1 & \pm 132.5 & \pm 247.1 \\
\hline
\end{tabular}

${ }^{a, b}$ Means in the same column with different superscripts are significantly different.

Reproductive rhythm: PP, post partum; P11, 11 days after parturition; PW, post weaning.

${ }^{1}$ APRI line; BB, Baladi Black breed.

Table 9. Interaction effects of postpartum re-mating interval $x$ breed on daily milk yield for doe rabbits after second parity (Means $\pm \mathrm{SE}$ )

\begin{tabular}{|c|c|c|c|c|c|}
\hline \multirow{2}{*}{ Parity time } & \multirow{2}{*}{ Breed } & & \multicolumn{3}{|c|}{ Next Parities } \\
\hline & & $M_{1}$ & $M_{2}$ & $M_{3}$ & $M_{4}$ \\
\hline \multirow{2}{*}{ PP } & APRI & $92.4^{\mathrm{a}} \pm 6.7$ & $102.1^{\mathrm{a}} \pm 7.4$ & $90.6^{\mathrm{bc}} \pm 6.5$ & $81.1^{\mathrm{abc}} \pm 5.6$ \\
\hline & BB & $76.4^{\mathrm{ab}} \pm 10.7$ & $89.2^{\mathrm{ab}} \pm 10.7$ & $76.5^{c} \pm 11.2$ & $62.4^{\mathrm{C}} \pm 11.0$ \\
\hline \multirow{2}{*}{ P11 } & APRI & $85.2^{\mathrm{ab}} \pm 7.5$ & $99.8^{\mathrm{a}} \pm 8.1$ & $106.4^{\mathrm{a}} \pm 7.3$ & $95.2^{a} \pm 6.5$ \\
\hline & BB & $74.7^{\mathrm{ab}} \pm 9.0$ & $78.9^{\mathrm{b}} \pm 9.8$ & $72.7^{c} \pm 9.6$ & $59.2^{c} \pm 9.8$ \\
\hline \multirow{2}{*}{ PW } & APRI & $91.3^{\mathrm{a}} \pm 7.3$ & $99.4^{\mathrm{a}} \pm 7.9$ & $97.9^{\mathrm{ab}} \pm 7.1$ & $90.4^{\mathrm{ab}} \pm 6.2$ \\
\hline & $\mathrm{BB}$ & $72.0^{\mathrm{b}} \pm 8.0$ & $92.0^{\mathrm{a}} \pm 8.4$ & $74.6^{c} \pm 7.8$ & $69.0^{\mathrm{bc}} \pm 7.3$ \\
\hline
\end{tabular}

${ }_{\mathrm{a}, \mathrm{b}, \mathrm{c}}$ Means in the same column with different superscripts are significantly different.

Reproductive rhythm: PP, post partum; P11, 11 days after parturition; PW, post weaning.

${ }^{1}$ APRI line; BB, Baladi Black breed. 
Effect of re-mating interval after the first parturition on the litter parameters, milk yield and reproduction traits of rabbit does

Table 10. Interaction effects of postpartum re-mating interval $x$ breed on body weight and reproductive traits for doe rabbits after second parity (Means \pm SE)

\begin{tabular}{|c|c|c|c|c|c|c|}
\hline \multirow{3}{*}{ Parity time } & \multirow{3}{*}{ Breed } & \multirow{3}{*}{$\begin{array}{c}\text { Doe } \\
\text { weight }(\mathrm{g}) \\
\text { At mating } \\
\end{array}$} & \multicolumn{4}{|c|}{ Next Parities } \\
\hline & & & \multicolumn{4}{|c|}{ Reproduction traits } \\
\hline & & & NSC & $\mathrm{DO}(\mathrm{d})$ & $\mathrm{KI}(\mathrm{d})$ & GL(d) \\
\hline \multirow{4}{*}{ PP } & \multirow{2}{*}{ APRI } & $3124.0^{b}$ & 1.52 & 15.8 & $50.7^{b}$ & $31.8^{a b}$ \\
\hline & & \pm 28.1 & \pm 0.13 & \pm 3.2 & \pm 3.2 & \pm 0.21 \\
\hline & \multirow{2}{*}{ BB } & $3080.6^{b}$ & 1.58 & 9.8 & $53.4^{\mathrm{ab}}$ & $32.0^{\mathrm{a}}$ \\
\hline & & \pm 38.3 & \pm 0.18 & \pm 4.9 & \pm 4.4 & \pm 0.28 \\
\hline \multirow{4}{*}{ P11 } & \multirow{2}{*}{ APRI } & $3217.1^{a}$ & 1.44 & 15.7 & $49.0^{b}$ & $31.3^{b}$ \\
\hline & & \pm 28.2 & \pm 0.13 & \pm 3.4 & \pm 3.3 & \pm 0.22 \\
\hline & & $3092.5^{\mathrm{b}}$ & 1.53 & 18.7 & $58.5^{\mathrm{a}}$ & $31.9^{\mathrm{a}}$ \\
\hline & & \pm 42.1 & \pm 0.20 & \pm 6.2 & \pm 5.0 & \pm 0.32 \\
\hline \multirow{4}{*}{ PW } & \multirow{2}{*}{ APRI } & $3241.3^{a}$ & 1.27 & 18.2 & $48.3^{b}$ & $31.2^{b}$ \\
\hline & & \pm 30.1 & \pm 0.13 & \pm 3.4 & \pm 3.3 & \pm 0.22 \\
\hline & \multirow{2}{*}{ BB } & $3086.0^{b}$ & 1.49 & 7.4 & $53.5^{a b}$ & $32.0^{\mathrm{a}}$ \\
\hline & & \pm 25.3 & \pm 0.15 & \pm 3.9 & \pm 3.8 & \pm 0.25 \\
\hline
\end{tabular}

${ }^{\mathrm{a}, \mathrm{b}}$ Means in the same column with different superscripts are significantly different.

Reproductive rhythm: PP, post partum; P11, 11 days after parturition; PW, post weaning.

${ }^{1}$ APRI line; BB, Baladi Black breed.

Results (Table 10) showed that reproductive traits (NSC, DO) traits in rabbits does were not significantly $(\mathrm{P}<0.05)$ affected by interaction of remating interval group and breed. While, these two parameters (KI, GL) and were significantly $(P<0.05)$ observed by their interaction (Table 10).

No significant differences were found for the does' body weight as affected by the length of period between the first kindling and the next insemination .Litter size(at Weaning) and daily milk yield at third and fourth week of suckling. In fact, Fortun-Lamothe et al (1999) observed a similar body composition of newborn offspring, independently of the reproductive rhythm of their dams, which may be achieved at the expense of their mother's body condition. Coureaud et al (2007) also observed mortality rates below $3 \%$ in the new born offspring weighing more than $48 \mathrm{~g}$ at birth. The present results shows that the body reserves in young females rabbit may control the success of reproduction after first parturition. The rabbit females after first parturition mobilize body reserves ensuring an adequate litter weight and daily milk yield in future reproductive rhythm. The body reserves mobilization observed in the pre-partum period is a natural reproductive strategy developed by rabbit females to ensure correct foetus development and thus offspring survival in the post-partum period. Based on the data available in the literature, the nulliparous rabbit females accumulate body reserves until the last $12 \mathrm{~d}$ of gestation and then mobilize the accumulated reserves, reaching the lowest body condition at parturition (Savietto et al 2016). This pattern is the inverse to that observed in sows (Sigfridson, 1996) and cows (Nielsen et al 2003), where the maximum body condition score is achieved at parturition. However, this high mobilization pattern of nulliparous rabbit females in late pregnancy has been already reported, when in vivo methods such as total body electrical conductivity (Bolet and Fortun-Lamothe, 2002) or bioelectrical impedance analyses (Rebollar et al 2011; Romero et al 2011) were used. Also, fat tissue accretion in the early lactation could be due to the fact that rabbits have evolved a fitness strategy to conceive just after parturition (Savietto et al 2016). The degree of fat tissue mobilization in late pregnancy and fat tissue recovery in early lactation seemed to condition the reproduction success during lactation (Savietto et al 2016). Our results confirmed that rabbit females start to invest their resources in the current litter in late pregnancy, using the body reserves to promote foetal growth and the onset of milk production.

Based on the results it can be concluded that applying a lengthened period after the first kindling (by more 10 days) or after weaning had a favorable effect on the does' production. 


\section{REFERENCES}

Bolet, G. and Fortun-Lamothe, L. 2002. Relationship between body condition and reproductive performances in rabbit does. In Proc.: 3rd Meeting of Workgroups 3 and 4. COST Action 848, pp. 24-25 October 2002, Ispra, Italy.

Bonanno, A., Mazza, F., DiGrigoli, A.A. and Alicata, M.L. 2004. Effects of restricted feeding during rearing, combined with a delayed first insemination, on reproductive activity of rabbit does. In: Proc. $8^{\text {th }}$ World Rabbit Congress, Puebla, Mexico, pp. 224-230.

Castellini, C., Dal Bosco, A. and Cardinali, R. 2006. Long-term effect of post-weaning rhythm on the body fat and performance of rabbit does. Reprod. Nutr. Dev. 46, 195-204.

Coureaud, G., Fortun-Lamothe, L., Langlois, D. and Schaal B. 2007. The reactivity of neonatal rabbits to the mammary pheromone as a probe of viability. Animal, 1, 1026-1032.

Duncan, D.B. 1955. Multiple Range and Multiple F Tests. Biometrics 11, 1-42.

Feugier, A. and Fortun-Lamothe, L. 2006. Extensive reproductive rhythm and early weaning improve body condition and fertility of rabbit does. Anim. Res. 55, 459-470.

Fortun-Lamothe, L., Prunier, A., Bolet, G. and Lebas, F. 1999. Physiological mechanisms involved in the effects of concurrent pregnancy and lactation on foetal growth and mortality in the rabbit. Livest. Prod. Sci., 60, 229-241.

Hilmy, A.F. 1991. Some productive aspects in rabbits. M.Sc. Thesis, Fac. Agric., Moshtohor, Zagazig Univ., Banha Branch, Egypt, 128 p.

Matics, Zs., Kustos, K., Gerencsér, Zs., Radnai, I., Nagy, I. and Szendrő, Zs. 2011. Effect of re-insemination interval after the first parturition on the performance of rabbit does. Giornate di Coniglicoltura ASIC 2011, pp. 59 -61.

Nielsen, H.M., Friggens, N.C., Lovendahl, P., Jensen, J. and Ingvartsen, K.L. 2003. Influence of breed, parity, and stage of lactation on lactational performance and relationship between body fatness and live weight. Livest. Prod. Sci., 79, 119-133.
Pascual, J.J. 2010. The role of body condition on new feeding and breeding programmers for reproductive rabbit does. pp. 11-32 in Proc. $22^{\text {nd }}$ Hungarian Confer. Rabbit Prod. Kaposvár, Hungary.

Rebollar, P.G., Pereda, N., Schwarz, B.F., Millan, P., Lorenzo, P.L. and Nicodemus, N. 2011. Effect of feed restriction or feeding highfiber diet during the rearing period on body composition, serum parameters and productive performance of rabbit does. Anim. Feed Sci. Tech., 163, 67-76.

Rommers, J.M., Meijerhof, R., Noordhuizen, J.P.T.M. and Kemp, B. 2002. Relationships between body weight at first mating and subsequent body development, feed intake and reproductive performance of rabbit does. J. Anim. Sci. 80, 2036-2042.

Romero, C., Nicodemus, N., Martinez de Morentin, C.G., Garcia, A.I. and De Blas, C. 2011. Effect of grinding size of barley and dehydrated alfalfa on performance and body composition of does during their early reproductive cycles. Livest. Sci., 140, 55-61.

SAS, 2001. User's Guide: Statistics, Version 8.1. SAS Institute Inc., Cary, NC, USA.

Savietto, D., Marono, S., Martinez, I., MartínezParedes, E., Ródenas, L., Cervera, C. and Pascual J.J. 2016. Patterns of body condition use and its impact on fertility. World Rabbit Sci., 24, 39-45.

Sigfridson, K., 1996. Feeding for longevity. Strategies for pregnant and lactating sows. In1 Proc.: NJF-seminar no. 265. Longevity of Sows, 27-28 March, 1996. Foulum, Denmark, pp. 46-51.

Szendrö, Zs., Gerencsér, Zs., Matics, Zs., BirónéNémeth, E. and Nagy, I. 2008. Comparison of two reproductive rhythms of rabbit does. In: Proc. $9^{\text {th }}$ World Rabbit Congress, Verona, Italy, pp. 455-458.

Xiccato, G. 1996. Nutrition of lactating does1. In: Proc. $6^{\text {th }}$ World Rabbit Congress, Toulouse, France, 1, 29-47.

Xiccato, G., Trocino, A., Boiti, C. and Brecchia, G. 2005. Reproductive rhythm and litter weaning age as they affect rabbit doe performance and body balance. Anim. Sci. 81, 289-296. 